\title{
СВОєРІДНІСТЬ ШЕВЧЕНКОВОГО РОЗУМІННЯ СвОБОДИ
}

\section{Т.О. Дроздова}

Проблема свободи належить до найскладніших фундаментальних проблем філософії. Можливо, це найскладніша проблема, що взагалі будь-коли поставала перед людством і філософією. «Про жодну з ідей, - зауважував Гегель, - не можна настільки вірогідно сказати, що вона непевна, багатозначна, доступна найбільшим непорозумінням i тому настільки їм піддається, як про ідею свободи, і про жодну не говорять зазвичай, так мало її розуміючи» [1, с.291]. Ще важче говорити про свободу як ідею стосовно поета, що оспівав її в умовах соціального, політичного, економічного поневолення свого народу, чиє ім'я, відтак, стало синонімом свободи не тільки для його нації, але й для усього світу, адже чуттєва спрага свободи - це одне, а осмислення, розуміння свободи як дуже непростої сенсожиттєвої проблеми зовсім інше, тим більше, коли йдеться про християнського мислителя, богошукача. Спроба реконструкції Шевченкового розуміння свободи в контексті християнської філософії і є метою даного дослідження.

У найзагальнішому плані виділяють чотири основні філософськосвітоглядні підходи щодо розуміння феномену свободи [8, с.3-16]. (Правда, у межах кожного із них спостерігаються досить різні трактування, оскільки, виходячи з близьких світоглядних настанов, автори концепцій часто доходили протилежних висновків i, навпаки, однакові висліди - іноді протилежні за своїми світоглядними витоками).

\section{1. Натуралістичний підхід.}

Його сутність полягає в тому, що «свобода - це сукупність спонтанних людських реакцій та поведінки, котрі не обумовлені будь-якими

Актуальні проблеми духовності 
зовнішніми по відношенню до людини чинниками» [8, с.15]. (Свобода - природна властивість, певна даність, яку треба захищати, коли їй загрожує небезпека). Передумови цього підходу склалися ще в античній філософіï, зокрема у поглядах Платона, що називав дійсно вільною ту людину, яка відчуває, думає та чинить відповідно до усвідомлення своєї космічної самодостатності і не підкоряється жодним, чужим ï природі, наказам. Але таке розуміння свободи сакралізує в якості природного право однієї особи керувати свободою інших, право сильної від народження людини. Тому, навіть виступаючи проти давньогрецької рабовласницької демократії, Платон не зміг запропонувати нічого кращого за утопічну модель держави військово-тоталітарного гатунку з жорсткою соціальною ієрархією (філософи-правителі, воїни і ремісники). Винайдене Платоном рішення породило не лише усталену традицію у європейському мисленні, а й наполегливі спроби втілити у життя такого роду утопії, що й продемонструвало аж надто наявно ХХ століття.

\section{2. Сочіально-детерміністсъкий підхід.}

Його прибічники визнають і пропагують лише цілковиту біологічну та соціальну детермінованість людських вчинків. Починаючи від нідерландця Спінози (автора формули свободи як пізнаної необхідності), парадигмальні настанови цього підходу активно розроблялися у соціальній філософії марксизму, згідно з якою свобода виявляється у свідомій діяльності для перетворення людиною необхідно примусових умов життя у корисні для неї. Таке розуміння свободи являє собою, по суті, не визначення, а заперечення їі: мало того, що місце свободи займає їі протилежність - необхідність,- людину, що прагне свободи, ще й змушують усвідомити цю необхідність. (Але ж раб від одного пізнання і усвідомлення свого рабства аж ніяк не стає вільнішим). Отже, такий підхід - відмова від свободи і насильство над своєю власною природою.

\section{3. Антиціннісно-елітаристсъкий підхід.}

Його зміст пов'язаний з оригінальною аксіологічною позицією у тлумаченні свободи. Сумніву піддається сама цінність свободи. Свобода оголошується порожньою, непотрібною і навіть небезпечною для «нормального» життя конкретної людини. В.Розанов, К. Ясперс, Е. Фромм кваліфікують відношення між свободою і особистістю як фундаментальне екзистенційне протиріччя, що, як правило, вирішується шляхом втечі від свободи: «Свобода принесла людині незалежність і 
раціональність існування, але водночас ізолювала її, пробудила в ній почуття безсилля і занепокоєння. Ця ізоляція нестерпна, і людина опинилася перед вибором: або позбутися свободи за допомогою нової залежності, нового підкорення, або піднятися до повної реалізації позитивної свободи» [9, с.8]. Досить неочікуваним прагматичним наслідком антиціннісних тлумачень свободи стала апологія елітарного суб'єкта свободи (свобода мислиться як modus vivendi Великої Особистості, як право на насильство у процесі оволодіння свободою небагатьма проти ycix).

\section{4. Суб’ективістсъкий підхід.}

Він формується у межах екзистенційних та феноменологічних теорій, де свобода уявляється як фундаментальна якість особистості. (Свобода - це вибір себе, на цей вибір болісно, але невідворотно приречена кожна людина, репресивно формуючи себе як особистість.) Цей підхід найпослідовніше виявився у трактуванні свободи Сартром, Камю, Аббаньяно.

На противагу Гегелевому тлумаченню свободи (за яким вона фактично розчиняється у світі) і Шопенгауеровому (свобода розчиняє весь світ у собі), Сартр пропонує інше вирішення проблеми. На його думку [6, с.25-138], два світи протистоять один одному: світ людської свободи та світ природи (всього матеріального). Матеріальний світ постає з речовин - аморфних, непевних, липучих субстанцій. Матерія, природа поглинає людину з їі творчою вдачею. Вона обволікає людину мокрою, брудною поверхнею предметів, не залишаючи просвіту, розчиняючи у своєму холодному череві все активне. Життєтворча діяльність людини, отже, не вкорінена в об'єктивний світ. Людська свобода - бентежна суб'єктивність, яка є чимось на зразок «розтискування» не просто байдужого, а й ворожого їй буття. Вона утворює у бутті щось схоже на отвір, пробоїну, «ніщо». «Ніщо» $є$ онтологічною основою людської суб'єктивності і свободи.

Не маючи на що спертися й не отримуючи нізвідки допомоги, людина приречена в кожну мить власного існування «віднаходити у собі людину». В цьому її свобідна сутність.

Звісно, окреслені підходи не вичерпують усього розмаїття уявлень про свободу. Поряд з названими в історії філософської думки існують сотні інших, не менш оригінальних. Але, як нам здається, усі ці філософські концепції не те щоб мало обходять пересічну людину, а виступають ніби вторинними щодо її особистісного вибору. Вона якщо і звертається до історичної філософської думки, то тоді вже, ко- 
ли визначилася, шукаючи у відомих мислителів підтримки, аналогії, співвідносності зі своїми власними уявленнями. I це не дивно, адже питання про свободу з кола так званих «вічних» або «сенсожиттєвих» поряд з питаннями про суть людини, її місце у світі, про щастя, добро i зло, важливих і насущних для кожного. Тому-то кожен і намагається у міру своїх сил дати на нього відповідь.

Той, перед ким виникає питання: вільний я чи ні і у якому сенсі? вочевидь відповість на нього спочатку так: бути вільним - означає діяти вільно, без перешкод здійснювати свої бажання; я вільний тоді, коли мені ніщо не заважає робити так, як хочеться. Справді, чому ми називаємо невільною людину у кайданах? Бо вона має потреби і бажання, здійснювати які заважають грати. А якщо людина з власної волі одягає кайдани або, перебуваючи за гратами, нічого ліпшого для себе не бажає? Вільна вона чи ні? ${ }^{1}$

Отже, поміркувавши так, людина обов'язково прийде від свободи дії (фізичної свободи, за визначенням Віндельбанда) до свободи духу. I якщо свобода дії, по суті, зводиться до влади над зовнішніми умовами, то свобода духу є владою людини над собою. I саме вона $є$ визначальною - свободу не можна дати, це не якийсь зовнішній стан, а завжди (і найперше) внутрішня гідність людини. Значить, щоб стати вільним, треба насамперед звільнити свій дух. Дійшовши ж такого висновку, людина з подивом помічає, що цей шлях більш як дві тисячі років тому вже був містично відкритий нам християнською релігією.

Новий Заповіт приніс ідею звільнення людської душі від всеохопного диктату старозаповітного Закону, й перед людиною відкрився простір вільного вибору, вільної жертви, вільної відповіді Богові. Впродовж тисячоліть історії християнства свобода утверджувалася як один 3 найглибших вимірів існування людини.

Фактично Христос власним прикладом показав нам, якою має бути досконала людина. Відкрив, що досягти цього можна, лише ставши вільним: «Якщо Син звільнить вас, то істинно вільними будете» (Іван. - 8:36). Тому найближчими до осягнення феномену свободи, як нам видається, були філософські вчення, що спиралися на християнську релігію (неотомізм, персоналізм). Адже самотній індивідуальний розум, лише індивідуальні зусилля не в змозі віднайти універсальну істину. Людина, приречена сама на себе, полишена сам-на-сам зі своїм «людським», доволі немічна і безсила. Сенс буття їй не відкривається.

\footnotetext{
${ }^{1}$ Сократ, приречений до страти, відмовляється від порятунку, здобутого ціною порушення афінських законів, демонструючи повагу до них. Він свідомо обирає смерть. Отже, по суті, чинить вільно.
} 
Тільки у прилученні до християнського розуму можна здобути свободу: «I пізнаєте істину, - а істина вас вільними зробить» (Іван. - 8:32). Гадаємо, саме Євангельський ідеал свободи обрав за основоположний для себе Шевченко. Оскільки ж слово «свобода» безвідносно до особистості-порожній звук, а поняття «християнська свобода» вимагає присутності Бога у будь-якому тлумаченні, мусимо перш за все спробувати побачити і людину, і Бога такими, якими бачив їх митець, тим більше, що, на наш погляд, якраз свобода і $є$ для Шевченка джерелом існування ідеального взаємозв'язку між людиною і Богом.

Про антропоцентризм Шевченка написано вже чимало. Найпослідовніше простежується він у ставленні Шевченка до природи. Шевченкова людина живе і діє на природі (всі головні події його балад, поем, повістей відбуваються у садках, полях, дібровах, на дорозі чи при дорозі). Якщо людина опиняється у хаті чи палатах, то там лише перебуває, інтер'єр поета мало цікавить. Але і природа, на переконливу думку Д. Чижевського, не має у Шевченка самостійного значення. Вона $є$ лише засобом розкриття людських переживань, «вдивляючись і вслухаючись в неї, людина чує і бачить лише себе саму» $[10$, с. $18-$ 19]. Природа відгукується на все, що діється у серці людини, вона $є$ лише символічним відображенням людських настроїв і почувань: «Садок вишневий коло хати...»-гармонія світоустрою; «І небо невмите, і заспані хвилі» - пекуча ностальгія; «Ми восени такі похожі...»-peфлексія, легкий смуток. Причому неважко помітити, що кожен Шевченків персонаж - це великою мірою він сам (його переконання, протиріччя, помилки, відкриття - його глибини). Має рацію Б.Рубчак, стверджуючи: «Єдиним шляхом до пізнання і вираження поетом реальності, а, отже, до освоєння її є покладання в основу своєї творчості власного вираженого „Я“ в різних його ролях і сполучування цих ролей в постійному процесі творення. Хоча Шевченко зумисне приховує свою особистість, уважний читач не може не відчувати в його манеpi могутній всеохоплюючий потік глибинної ідентичності, з якого на поверхню зринають різноманітні поетові ролі» [4, с. 19]. Дійсно, саме на прикладі Шевченка переконуєшся у певнім сенсі давньої китайської мудрості: що і як би людина не говорила, вона завжди говорить лише про те, ким $є$ насправді. Та настільки переповненого собою поета, як Шевченко, все ж знайти важко.

Тут йому легко було б закидати суб'єктивізм, егоїзм, егоцентризм, притаманний крайнім виявам індивідуалізму, але індивідуалістом (принаймні у негативному значенні цього слова) Шевченко не був. Всією своєю творчістю, власним життям поет послідовно втілю- 
вав у життя ідеї персоналізму [12, с.413-418]. Цей погляд належить В. Ящуну, думки якого ми в основному і розділяємо. Звісно, персоналістом назвати Шевченка не можна, хоча б з огляду на те, що як самостійна течія персоналізм сформувався на початку XX сторіччя, але те, що поетові думки перебували у персоналістській парадигмі трактування особистості (концепція людини, що постає на характерній для теїзму персоніфікації Бога, яка інспірує гостро значиме акцентування неповторності та максимальної цінності людської особистості), помітити легко.

Індивідуалізм - одна зі світоглядних течій натуралізму, що базується на раціоналізмі та позитивізмі. Основоположним в індивідуалізмі проголошується егоїзм та егоцентризм у контрасті до альтруїзму. На перший план висувається «Я» індивіда $з$ його особистими інтересами. Це «Я» $є$ центром світогляду людини. Позитивними рисами індивідуалізму $є$ визнання рівності всіх людей з морального погляду, тому одна людина не може бути засобом для добробуту іншої; визнання за кожною людиною права на найбільшу свободу у її виборі і досягненні цілей, оскільки це стимулює ініціативу, розвиток ресурсів, що у підсумку зумовлює зростання добробуту у суспільстві. Негативним явищем індивідуалізму є те, що загальне добро індивід завжди розглядає під кутом зору особистої користі. Він намагається здійснювати свої плани навіть тоді, коли вони ідуть врозріз із загальним благом спільноти. Ще однією неприйнятною рисою індивідуалізму є еготизм - перебільшена думка про себе, свою гідність і значення. Еготист самозакоханий і зарозумілий. Не бажає ні бачити, ні визнавати своїх недоліків.

На відміну від індивідуалізму з його егоїзмом, егоцентризмом та еготизмом, спрямованими на ствердження індивідуального «Я», протиставлення його суспільності, персоналізм цінує людську особистість у всій їі повноті. Хоча центром особистості він, як і індивідуалізм, визнає «Я» людини, та вважає, що буття було б неповним, коли б не мало зв'язків 3 іншими «Я». Тому зустріч «Я» 3 «и», що переживається як особлива цінність, виводить персональну свідомість на надіндивідуальний, але так само персонально артикульований рівень, звідси таке велике значення надається спілкуванню, тоді як індивідуалізм веде людину радше до самовідокремлення, а спілкування цінує лише як засіб для досягнення особистих цілей.

Обидві філософські течії наголошують на пріоритеті свободи. Однак індивідуалізм визнає у ній лише «Я» індивіда (яскравий приклад індивідуалістської свободи демонструє Пер Гюнт Г. Ібсена, гарячково стверджуючи свою індивідуальність, він так і не спромігся стати со- 
бою, шукаючи свободу, втратив її, став рабом власного «Я»), а персоналізм - бажання дати іншим.

Якщо пройнятий негативними настановами індивідуалізму може стати невільником настроїв, почувань, думок, що тиснуть на його самостверджувальне «Я», то персоналіст своїм свідомим «Я» буде розсудливо обирати лише ті з них, що не йдуть врозріз із загальним добром інших. «Інстинктивні спокуси користолюбства зовнішнього світу,- пише В. Ящун,- теж влітали у підсвідомість поета та намагалися втиснутись у центр його підсвідомості [...] Однак Шевченкове „Я“ їх побороло непримиренним „караюсь, мучусь, але не каюсь“. Цей шлях страждальця він вибрав не для самоствердження [...], а для обмеження страждання своїх ближніх - синів і дочок поневоленої України» $[12$, с.416]. Дійсно, Шевченко мав на своєму шляху багато спокус: був модним поетом, якого з радістю приймали у найвищих колах; улюбленцем дам; талановитим художником із блискучою перспективою; зрештою, феноменом розуміння становища свого народу в минулому, сучасному та проекцією у майбутнє переріс всіх своїх сучасників і був свідомий того, відчував важливість своєї місії. Але не виявляв ні пихи, ні зарозумілості, ні зневаги до ближніх. Волів бути доброю людиною, мріяв, аби добрих людей було більше навкруги. Тяжким болем, а не мізантропічною звихненістю або зневагою до зіпсутої злої людської природи покликані були спопеляючі інвективи, жорстокі своєю правдою слова, що лунали з його уст на адресу людини. Почувався нещасним і одиноким не стільки через власну упослідженість, як через горе інших, що звідусіль волало до нього. Індивідуаліст може почуватися щасливим і тоді, коли навкруги багато нещасливих. Персоналіст, навпаки, бачить своє щастя тільки поряд зі щастям ближнього, щастям свого народу. Чи не найбільшим виявом поетової любові до людей став його «Заповіт», сперечаючись про який ламало списи не одне покоління дослідників [5, с.41-49], які в основному на підставі поетового «А до того - я не знаю Бога!» намагалися з'ясувати Шевченкові стосунки з Господом. Як на нас, то у «Заповіті» жодною мірою не виявлено якогось особливого ставлення до Бога, як спостерігаємо це у інших віршах митця. Тут йдеться радше про його самоозначення, про місію, яку свідомо перебирає на себе Шевченко, місію й по смерті, як і за життя, стояти на сторожі «малих отих рабів німих», аж доки не здійсниться справедливість. Тож фразу «А до того - я не знаю Бога» розуміємо як обітницю перед лицем власного народу, подібну до тої, що її дав іудейський Бог Яхве, який після зруйнування Єрусалимського Храму, коли єврейське плем'я було розсіяне по світах, приносить, за версією 
кабалістів, зворушливу присягу, що не увійде в Єрусалим небесний, аж поки сини Ізраїлю знову не ввійдуть у Єрусалим земний: «Як забуду тебе, Єрусалиме, хай забуде Мене правиця Моя!»- мало не в розпачі клянеться Яхве. Причому Шевченко не просто ототожнює себе з Яхве чи Христом у плані спокути, страждання за гріхи інших. Очевидно, тут розгортається не стільки мотив жертовності, скільки мотив відповідальності, навчительства (апостольства: я не залишу свій народ доти, доки він не буде порятований, доки не вийде з духовної неволі). Цей мотив звучить і в інших творах митця («Посланії», «Гайдамаках», найбільш виразний він у пізнішому «Буває, в неволі іноді згадаю...»). Отже, «Заповіт», на нашу думку, - це прагнення утвердити ідеальний образ людини, що намагається вповні виконати свій обов'язок, виявити себе зовсім вільною, оскільки ступенем людської свободи визначається і ступінь її відповідальності. В моралі людина відповідальна не тільки за себе, а й за інших тою мірою, якою визнає їх своїми-іншими (частиною своєї суверенності, продовженням себе самої). Шевченко не відділяє себе від свого народу, про що й пише у листі до редактора «Народного чтения» О. Оболонського: «История моей жизни составляет часть истории моей родины» [11, с.452], тому й покладає на себе відповідальність за нього. Така позиція зближує Шевченка з Сартром, який був упевненим, що «наша відповідальність багато більша, ніж ми можемо собі уявити, вона обіймає все людство» [7, с. 324].

Варто погодитись з думкою Д. Козія щодо відношення Шевченка до людини: «Любов до ,малих“, убогих і принижених - це любов, якою пронизане життя Шевченка і шевченківської людини. Вона має пронизливий зір і шукає в простій людині рис справжньої людини. Вона роздаровує, нічого не втрачаючи, навпаки, роздаровуючись, внутрішньо росте. Це спонтанний порив до самопожертви, що випливає 3 надміру сил. Це невимушена готовність ділитися всім з тими, хто потребує. Для „новітньоі“ людини, яка втратила почуття зв’язку з метафізичною глибиною буття, незрозумілою мусить бути великодушність шевченківської людини, її нестурбованість справами власного добробуту, нестурбованість, яка випливає з довіри до буття. Серце люблячої людини лежить не в „Я“, а в „Ми“. <..> Ії спілкування з приниженою людиною прагне допомогти тій людині випростатись і відчути в собі людську гідність» [3, с. 52]. Звідси і відчайдушне прагнення свободи для такої людини. Втім, виглядає так, що світобачення Шевченка роздирають глибокі протиріччя. 3 одного боку, у всьому світі начебто немає свободи, і вона є недосяжною, панує необхідність, доля, причому зла доля (фатум) - тоді Бог трансцендентний світові і людині, Він 
$\epsilon$ чинником несвободи («В неволі, в самоті немає..», «Світе милий, світе тихий... », «Минули літа молодії. .. »), з іншого, існує палке бажання свободи для себе особисто, свободи для покріпаченого селянства, свободи для підневільної нації. Але поет розуміє, що коли людина морально не готова прийняти ту свободу, а значить, і відповідальність, то i, отримавши свободу ззовні, стати вільною не зможе. Причому та свобода не свобода від Бога, а свобода з Богом, оскільки Він як Деміург, створивши людину за образом Своїм і подобою, сотворив ï̈ подібно до Себе вільним творцем, тож і не вимагає від людини покори і послуху. Усвідомлення того $є$ досить важким для людини, адже антиномія свободи та необхідності неминуча у релігійному житті, причому її не можна усунути раціоналістично та логічно. Вона знімається суто релігійним досвідом. Кожен носить у собі цю концепцію амбівалентності Бога - говоримо ж «Бог над нами» $\mathrm{i}$ «Бог в нас, у нашім серці», i кожен, хто шукає відповідей, мусить пройти тим шляхом. Шевченко повністю усвідомлює його невідворотність. I, то з гіркотою, мало не у розпачі, бо ходив ним не раз («В неволі, в самоті немає...»), то 3 надією, бо ж і до істини не раз наближався («За сонцем хмаронька пливе...»), констатує це.

Граничної емоційної напруги досягає відчуття роздоріжжя у невільницькому «чи то недоля чи неволя... ». Рефлективно роздумуючи над причинами, що призвели до нинішньої скрути його колись чисту душу:

Чи то недоля чи неволя,

Чи то літа ті, летячи,

Розбили душу,-

поет раптово вибухає гнівом проти людей, але не проти усіх, лише проти тих (підкреслює ж: «нехристияне!»), що йшли супроти Божих заповідей любові і добра, що своїми неправедними діями спричинилися до панування зла і неволі, змусили і його засумніватися у Божій любові («писать погані вірші научили»), збитися на манівці («Тепер іду я без дороги, без шляху битого»). Але так само раптово спалах роздратування минає, і вже у зовсім іншій тональності, тяжко страждаючи від незаслуженої образи, поет підсумовує:

Дивуєтесь, що спотикаюсь,

Що вас і долю проклинаю.

I плачу тяжко, i, як ви...

Душі убогої цураюсь, 
Своєї грішної душі!

Старозавітний образ Бога-Володаря, Бога-Судді усувається у Шевченка перед трагічним образом Бога любові, що іманентний людям і страждає разом з людьми. Бо тільки такому Богові можна відкритися у сокровенних мріях і розчаруваннях («Мій Боже милий, знову лихо!..»), тільки такому «хочеться сповідатися, серце розповити...» («Ми восени такі похожі...»). Зрештою, і співчувають лише такому Богові («Дівча любе чорнобриве»). Отже, трансцендентність, віддаленість Господа - провина не Божа, а людська («Коли б ті діти не росли, / Тебе, Святого, не гнівили, / Що у неволі народились / I стид на Тебе понесли» («Один у другого питаєм»), бо якраз людина не хоче побачити Бога у собі, їй легше перекласти відповідальність на Нього, відмовившись від власної свободи, тому не розуміє чи не хоче зрозуміти, що Всевишньому не потрібні раби, не потрібна покірливість. Йому потрібні сини, які б з власної волі обрали любов до Нього, прийняли Його цінності. Найточніше, як нам здається, зв'язок між Богом, людиною та її свободою, як їх розуміє Шевченко, характеризують рядки з поезії «лікері» :

... не осудить Бог,

Карать і миловать не буде:

Ми не раби Його - ми люде!

Дещо пізніше, але про це ж російський філософ В. Лосський скаже, що образ Божий в людині - це особистість як свобода.

Та, якби не було Христа, визнати Бога-Страдника було б важко. Поета гнітить страшенно, що люди не прийняли Христа, себто не повірили у Божу любов та істину. Його палкі запити: «За кого ж ти розіп'явся, Христе, Сине Божий?» («Кавказ»), «Шо він зробив їм, той святий, той Назорей, той Син єдиний Богом ізбранної Марії, що він зробив їм?» («Неофіти») - радше і не запити до Бога-Сина і БогаОтця, а докір людям за їхню незрячість. Так само, гадаємо, варто трактувати і рядки зі «Сну» («Гори мої високії...»): «Наробив ти, Христе, лиха! А переіначив людей божих?!», а не у плані проблем у стосунках Шевченка із Богом-Сином [2, с. 70].

Наважимось припустити, що й Христа робить поет цілковитою людиною, аби донести до інших суть, яка йому вже відкрилася: образ Божий у кожнім 3 нас. Все потенційно нам уже дано, і тільки від людини залежить прийняти чи ні «в живую душу світ незримий». До слова, Шевченко зовсім не поодинокий ні у антропологізаціїі Христа 
(до і після нього це робили Арій, Д.-Ф.Штраус, П. Тейяр де Шарден), ні в ствердженні його визначальної ролі для усвідомлення людської свободи (наш сучасник, протестантський теолог П.Ван Бурен, називає Христа людиною-для-інших, вільною людиною, вільною віддати себе іншому, яка надихає бути вільними інших; I. Нольте вважає Iсуса істинним знаком свободи, яка визначається любов'ю і зміст якої розкривається в ньому).

Отже, роздумуючи над долею свого народу, скутого путами соціально-економічної та національно-політичної неволі, Шевченко доходить висновку, що це-наслідки іншої, духовної, неволі, комплексу раба, лише позбувшись якого людина може стати дійсно вільною. За основоположний для себе поет обирає Євангельський ідеал свободи, яка, на його погляд, міститься у первозданній природі буття. Саме свобідна суть людини і $є$ першопричиною зла на землі (коли людина відмовляється від свободи, чинить зло супроти себе, коли зловживає, то свобода перетворюється на сваволю, тоді від зла страждає не лише сама людина, але й інші). Таким чином, Шевченко знімає з Господа відповідальність за зло, що заполонило світ. Відкриває, і для себе також повсякчасно, істинну сутність Бога, який не суддя і володар, а Любов, Совість, Жертовність.

\section{1 Бібліографія}

[1] Гегель Г. Философия духа // Гегель Г. Сочинения.-М., 1956.T.3.

[2] Діброва В. Поет як структура рідної стихії // Сучасність.1997. - Ч. 7-8.

[3] Козій Д. Ідея «праведного закону» у Шевченка // Сучасність.1976. - Ч. 3.

[4] Рубчак Б. Іронічні ролі «я» в поезії «Кобзаря»: профілі і маски // Слово і час. - 1993. - Ч. 3.

[5] Рудницький Л. А до того-я не знаю Бога // Сучасність.1989.- Ч. 5 .

[6] Сартр Ж.-П. Тошнота // Сартр Ж.-П. Стена. Избр. произведения. - М., 1992. 
[7] Сартр Ж.-П. Экзистенциализм - это гуманизм // Сумерки богов. - М., 1989.

[8] Судакова H. Свобода і ненасилля в сучасному суспільному розвитку: соціально-філософський аналіз: Автореф. дис. докт. філософ. наук. - K., 1998.

[9] Фромм Э. Бегство от свободы. - М., 1990.

[10] Чижевсъкий Д. Шевченко і Штравс // Слово і час. - 1999. - Ч. 3.

[11] Шевченко Т. Твори: У 5 томах - K., 1971.-Т. 5.

[12] Ящун В. Тарас Шевченко в світлі індивідуалізму та персоналізму // Визвольний шлях. - 1987. - Ч. 4. 